This series is published by the

University of Oslo Department of Economics

P. O.Box 1095 Blindern

N-0317 OSLO Norway

Telephone: +4722855127

Fax: $\quad+4722855035$

Internet: http://www.oekonomi.uio.no/

e-mail: $\quad \underline{\text { econdep } @ \text { econ.uio.no }}$
In co-operation with

\section{The Frisch Centre for Economic Research}

Gaustadalleén 21

N-0371 OSLO Norway

Telephone: $\quad+4722958820$

Fax: $\quad+4722958825$

Internet: http://www.frisch.uio.no/

e-mail: $\quad$ frisch@,frisch.uio.no

List of the last 10 Memoranda:

\begin{tabular}{|ll|l|}
\hline No 34 & $\begin{array}{l}\text { Finn Roar Aune, Rolf Golombek and Sverre A. C. Kittelsen } \\
\text { Does Increased Extraction of Natural Gas Reduce Carbon Emissions?. } \\
40 \text { pp. }\end{array}$ \\
\hline No 33 & $\begin{array}{l}\text { Christoph Schwierz } \\
\text { The Effects of Taxes and Socioeconomic Variables on Market Work and } \\
\text { Home Production in Norway in the Years 1970 to 2000. 61 pp. }\end{array}$ \\
\hline No 32 & $\begin{array}{l}\text { John K. Dagsvik, Steinar Strøm and Zhiyang Jia } \\
\text { A Stochastic Model for the Utility of Income. 39 pp. }\end{array}$ \\
\hline No 31 & $\begin{array}{l}\text { Karine Nyborg, Richard B. Howarth, and Kjell Arne Brekke } \\
\text { Green consumers and public policy: On socially contingent moral } \\
\text { motivation. 25 pp. }\end{array}$ \\
\hline No 30 & $\begin{array}{l}\text { Halvor mehlum } \\
\text { A Finer Point in Forensic Identification. 11 pp. }\end{array}$ \\
\hline No 29 & $\begin{array}{l}\text { Svenn-Erik Mamelund } \\
\text { Effects of the Spanish Influenza Pandemic of 1918-19 on Later Life } \\
\text { Mortality of Norwegian Cohorts Born About 1900. 30 pp. }\end{array}$ \\
\hline No 28 & $\begin{array}{l}\text { Fedor Iskhakov } \\
\text { Quasi-dynamic forward-looking model for joint household retirement } \\
\text { decision under AFP scheme. 59 pp. }\end{array}$ \\
\hline No 27 & $\begin{array}{l}\text { Henrik Wiig } \\
\text { The Productivity of Social Capital. 22 pp. }\end{array}$ \\
\hline No 26 & $\begin{array}{l}\text { Tao Zhang } \\
\text { Identifying treatment effects of active labour market programmes for } \\
\text { Norwegian adults. 45 pp. }\end{array}$ \\
\hline No 25 & $\begin{array}{l}\text { Tao Zhang } \\
\text { A Monte Carlo study on non-parametric estimation of duration models } \\
\text { with unobserved heterogeneity. 89 pp. }\end{array}$ \\
\hline
\end{tabular}

A complete list of this memo-series is available in a PDF® format at: http://www.oekonomi.uio.no/memo/ 


\title{
Social Democracy as a Development Strategy
}

\author{
Karl Ove Moene \\ Department of Economics \\ University of Oslo \\ Michael Wallerstein \\ Department of Political Science \\ Northwestern University
}

October, 2002

An earlier version of this paper was presented at the Conference on Globalization and Egalitarian Redistribution, Santa Fe Institute, May 2002. We thank Pranab Bardhan and the participants at the conference for comments. 
"It is but equity besides, that they who feed cloath and lodge the whole body of the people, should have such a share of the produce of their own labour as to be themselves well fed, cloathed and lodged" (Adam Smith 1776).

"One has to understand that the ongoing crisis is not a crisis of real poverty, but an organizational crisis. The world is like a ship loaded with the goods of life, where the crew starves because it cannot figure out how the goods should be distributed" (Ragnar Frisch 1931).

\section{Introduction}

Social democracy, it is often said, is nice but pricey. Whatever its merits in the rich countries of Western Europe, social democracy is frequently dismissed as an infeasible model for developing countries. Based on generosity towards the poor and protection against market competition, the argument goes, social democracy is only possible in consensual, homogeneous and affluent societies with an extraordinary commitment to equality. In third world countries that are conflict-ridden, heterogeneous and poor, does the social democracy have any relevance?

In this article we offer a more agnostic view of the feasibility of the social democratic model of development in the third world. First, we argue that consensus, homogeneity, and affluence are products of the social democratic model, not prerequisites. Second, we claim that the central social democratic policy as a development model was the policy of wage compression attained through highly centralized wage-setting institutions. Third, we argue that the economics benefits of wage compression would be as significant in South Africa, Brazil or India today as they were in the Nordic countries between 1935 and 1970. The political feasibility of a policy of wage compression, however, is open to doubt, hence our agnosticism regarding whether or not the social democratic road to affluence can be repeated. 
In this paper we consider social democracy to be model of development rather than an end state. In particular, we will not enter into the debate regarding the future prospects of social democracy in Western Europe within the context of European economic integration, a common currency, an aging population and the ever increasing cost of providing the best health care that money can buy. The achievements of social democracy as a development strategy in terms of combining the socialist virtues of equality and security without losing the capitalist virtues of economic efficiency and technological dynamism are not seriously in dispute. What are disputed are the answers to the following questions: What was the contribution of specifically social democratic policies to the high level of affluence and equality in Northern Europe today. Would the policies that successfully promoted development in Northern Europe be equally effective and feasible in the third world in the context of an increasingly integrated global economy?

\section{Nordic Exceptionalism}

Social democracy in the Nordic countries can be characterized in multiple ways. In political terms, social democracy represented the mobilization of industrial workers such that workers' organizations exercise significant power in both the labor market and in government. Unions negotiate the terms of employment for most of the labor force and exert a strong influence in politics through close connections to a social democratic party. The social democratic party is the largest party in parliament and a frequent participant in government. In Norway and Sweden, in particular, the social democratic party enjoyed a long period of uninterrupted government (1935-1965 in Norway, 19331976 in Sweden). Institutionally, social democracy was distinguished by the growth of a 
large welfare state, the organization of encompassing and centralized trade unions and the establishment of a system of routine consultation and cooperation between government, union and employer representatives that has been given the label "corporatism" in political science.

In terms of social policy, social democracy in the Nordic countries was characterized by a wage policy of "solidaristic bargaining," that is a commitment to reduce wage inequality, and a welfare policy of providing basic goods and services to all as a right of citizenship. In trade policy, social democratic governments embraced free trade. Protection was viewed as an ill-conceived subsidy to inefficient employers who did not deserve public support. Financial markets, however, were not open to international competition. In Norway, social democratic governments maintained extensive controls on the allocation of credit. Swedish governments were more concerned with guiding the timing of investment rather than the allocation of credit among prospective borrowers. In neither country were financial markets deregulated until the 1980s. The flexibility of capitalism allowed social democrats to finesse the one major demand that defied compromise with non-socialist parties: the elimination of private concentrations of wealth. Adopting the economics of Keynes and Frisch rather than of Marx, social democrats sought to construct a system of incentives that would lead private businesses to act in socially desirable ways without altering property rights.

In this paper, we focus on the policy of solidaristic bargaining, that is the policy of reducing wage inequality through centralized collective bargaining and, in Norway and Denmark, occasional government involvement. This is not because other social democratic policies, such as social insurance programs and free trade, are unimportant. 
But the policy of solidaristic bargaining was the most innovative and most distinctive policy associated with social democracy. ${ }^{1}$ A commitment to free trade was shared with liberal parties, while a commitment to social insurance was shared with all parties other than the liberal parties (Hicks 1999, Huber and Stephens 2001, Wilensky 2002). The non-socialist governments in France intervened in credit markets as much or more than the social democratic governments in Northern Europe in the early postwar period. Only the social democrats, however, explicitly promoted the reduction of inequality among wage earners as a development strategy. Whatever the impact of solidaristic bargaining on development, the policy was highly effective in compressing the wage distribution. By all measures, Scandinavia had the most egalitarian wage structure of any advanced industrial society by the 1970s (Freeman 1988, Wallerstein 1999)

How should the social democratic success in reducing inequality be explained? The most common explanations emphasize the importance of social homogeneity (Alesina, Glaeser and Sacerdote 2001), a socialist (or Nordic) commitment to equality (Therborn 1986), a consensual model of decision-making (Wilensky 2002) and affluence. But conditions in Norway and Sweden in the period preceding the social democratic ascent to power were anything but consensual, egalitarian and affluent.

In the 1920s and early 1930s, Norway and Sweden experienced the highest levels of industrial conflict in the world. In Norway the number of working days lost in strikes and lockouts in one year--1931--was three times larger than the total number of working days lost in industrial conflict the 25-year period 1945-1970. In one of the first studies of comparative industrial conflict, Ingham (1974) contrasted the extraordinary radicalism 
of Nordic workers with the relative docility of English workers during the inter-war years.

Nowhere else were employers as ready as employers were in Norway and Sweden to fight the unions with lockouts. The consensus between employers and unions that characterized social democracy after the war was nowhere to be seen when the social democrats entered government in the 1930s.

While the Nordic countries were relatively homogeneous in terms of religion and language, the working population was far from homogenous in terms of living conditions. In particular, the social and economic cleavages between rural and urban residents were striking. In 1934, Norway had 750 municipalities. Average income per capita in rural municipalities was one third of the per capita incomes of urban municipalities. But referring to the difference in the average understates the extent of regional inequality. Measured by income per capita, the gap between the poorest and richest rural municipalities was 1 to 14 , the gap between the poorest and richest cities was 1 to 4 and the gap between the poorest rural municipalities and the richest cities was 1 to18 (Falk and Tovmo 2000). As in most poor countries today the numbers exaggerate the real inequality because home production in subsistence farming and fishing is underreported. Nevertheless, Scandinavian social democrats came to power in societies no less economically divided than many poor countries of today.

As in developing countries today, there was significant underutilization of labor in Norway and Sweden when the social democrats came to power. Surplus labor in the form of open unemployment was most evident. The rate of unemployed union members, the only official statistics available, was, in 1921, as high as 18 per cent in Norway and 
27 per cent in Sweden. The rate fluctuated during the inter-war period, but never dropped below 9-10 per cent. The peak of unemployment was reached in 1933 with 33 per cent unemployment in Norway and 23 per cent in Sweden. How representative these numbers are for the total rate of unemployment is debated. ${ }^{2}$ Many union members who lost their modern sector job returned to the countryside to work on family farms or on farms owned by relatives. Yet, it is clear there was a large surplus of workers relative to the number of jobs even before the sharp decline of employment in the 1930s.

In addition, there was disguised unemployment in the countryside that may have been as significant as open unemployment in the cities. Around half of the population lived in sparsely populated areas where most made a living from farming and fishing. Many of these workers lacked a job that offered steady income. The common practice of sharing work and income among family members in rural areas meant that remaining family members would work more if some members left for the cities. A withdrawal of part of the work force could, therefore, leave production unchanged. Thus, according to the production test of employment (Sen 1975), there was widespread disguised rural unemployment throughout the inter-war years.

Finally, the economies that the social democrats inherited in the 1930s were far from affluent. As Table 1 illustrates, the real per capita GDP of Sweden and Norway when the social democrats entered government (1933 in the case of Sweden, 1935 in the case of Norway) was far below the current real per capita GDP of middle-income countries like Brazil or South Africa. In fact, the per capita GDP of Brazil and South Africa today is comparable to the per capita GDP of Norway and Sweden in the 1950s. If 
Norway and Sweden could afford an ambitious, egalitarian wage policies in the 1950s, so can Brazil and South Africa today.

\begin{tabular}{|l|c|}
\hline \multicolumn{2}{|c|}{ Table 1 } \\
Real per capita GDP (1996 USD) \\
\hline Norway 1935 & 4081 \\
\hline Sweden 1933 & 4535 \\
\hline Norway 1950 & 6598 \\
\hline Sweden 1951 & 7731 \\
\hline Brazil 1998 & 7103 \\
\hline South Africa 1998 & 7481 \\
\hline $\begin{array}{l}\text { Sources: Penn World Tables 6.0 (Center } \\
\text { for International Comparisons 2002); } \\
\text { Maddison (1964). }\end{array}$ \\
\hline
\end{tabular}

Other economic and social indicators tell similar stories. Norway was less urbanized in the 1930s than Brazil or South Africa today. The share of GDP generated by agriculture and fishing was greater in Norway in 1930 or in 1960 than in Brazil or South Africa today, as illustrated in Table 2. Northern Europe became rich under social democratic government, not before.

\begin{tabular}{|c|c|c|c|}
\hline \multicolumn{4}{|c|}{$\begin{array}{c}\text { Table } 2 \\
\text { Share of GDP by Sector }\end{array}$} \\
\hline & $\begin{array}{l}\text { Agriculture and } \\
\text { Fishing }\end{array}$ & $\begin{array}{l}\text { Manufacturing, } \\
\text { Mining and } \\
\text { Construction }\end{array}$ & Services \\
\hline Norway 1930 & 16.7 & 30.4 & 52.9 \\
\hline Norway 1960 & 9.0 & 32.4 & 58.6 \\
\hline Brazil 2000 & 7.0 & 29.0 & 64.0 \\
\hline South Africa 2000 & 3.0 & 31.0 & 66.0 \\
\hline
\end{tabular}

Social Democratic governments came to power in Sweden and Norway in the midst of the Great Depression committed to reducing unemployment and alleviating poverty. The main slogan of the social democrats in the thirties was employment for everybody, which was a popular demand under the circumstances. Both governments 
increased government spending on policies such as unemployment benefits, public housing and agricultural price supports. It is debated how much of the subsequent recovery in Norway and Sweden was due to the relatively cautious Keynesian policies implemented by the Social Democratic governments, and how much was due to the economic recovery of Germany and the consequent recovery of export markets.

In retrospect, the key innovation was not the Keynesian policies that were adopted in the 1930s, but the institutional response to the problem that threatened the recovery program: What would keep the increased government spending from raising the wages of insiders in the labor market, rather than increasing employment? The problem came to a head in both countries in the construction industry. ${ }^{3}$ Construction workers in Sweden and Norway were highly paid (although their work is seasonal), militant and sheltered from foreign competition. When foreign demand collapsed in the 1930s, workers in the export sectors such as metal workers accepted large wage reductions in order to stem the decline of employment. Construction workers came under no such pressure, in large part because of increased government spending on housing. Since construction workers were employed in the export sector as well as in home construction, higher construction wages raised labor costs in the export sector, which threatened the jobs of metalworkers. When construction unions called a strike in support of higher wages, the national confederation of unions intervened to force the strike to an early and. from the construction workers' point of view, unsuccessful conclusion.

The intervention of the national union confederation to end the strikes in construction was the initial step in a process of centralization of authority within the union movement in both Norway and Sweden, a process that was encouraged and 
supported by employers. "Basic agreements" between the national associations of unions and employers establishing rules for collective bargaining at the industry-level were reached in 1935 in Norway and 1938 in Sweden. In the 1950s, (1956 in Sweden, 1958 in Norway), bargaining at the industry level was replaced by direct negotiations over pay by the national associations of unions and employers. As white-collar and professional union confederations joined the centralized negotiations, the coverage of the central agreements expanded to include most of the working population in the private sector. ${ }^{4}$

The central agreements were necessarily general. The details of how the agreement were to be implemented was decided by subsequent bargaining at the industry and local level. Once the central agreement was signed, however, work stoppages were illegal. Wage increases at the local level were limited to what could be obtained without the threat of a strike.

The centralized system of wage setting, which reached its zenith in the 1970s, had three important consequences. The first was the virtual elimination of industrial conflict. From the countries with the highest levels of strikes and lockouts in the world in the inter-war year, Norway and Sweden became countries with some of the lowest levels of industrial conflict in the postwar period. The second consequence was to allow conditions in the export industries to determine the growth of wages throughout the economy. In practice, the centralized system of wage bargaining tied wage growth throughout the economy to the growth of wages in the export sector, since the unions in the export sector, the metal workers in particular, were the largest and most influential unions within the national confederations. 
The third consequence of centralized wage setting was a gradual process of wage compression that, over time, generated the most egalitarian distribution of wages and salaries in the capitalist world. In the 1950s, wage compression was adopted as an explicit goal of the unions in both Norway and Sweden under the title of "solidaristic bargaining." But wage compression is closely associated with the centralization of wagesetting in all advanced industrial societies, whether the centralization is achieved by centralized collective bargaining or by government intervention in the form of incomes policies and whether or not wage compression is adopted as an explicit goal (Wallerstein 1999).

While wage compression fit easily with the socialist heritage of the unions, the goals of solidaristic bargaining were defended more in terms of efficiency than in terms of equity. In the 1950s, two Swedish trade union economists, Gösta Rehn and Rudolf Meidner (Rehn: 1952), argued that equalizing wages across Swedish firms and industries would promote economic development by forcing wages up in low-productivity firms or industries and keeping wages down in high-productivity firms or industries. In a decentralized bargaining system, wages vary according to the productivity of the firm and the industry. In a centralized system, in contrast, wages are relatively insensitive to the profitability of the enterprise. On the one hand, industries with low levels of productivity are prevented from staying in business by paying low wages with a centralized system of wage determination. On the other hand, workers in industries with high levels of productivity were prevented from capturing much of the productivity differential in the form of higher wages. By reducing profits in low-productivity firms and increasing profits in high-productivity firms, labor and capital would be induced (or coerced) to 
move from low productive to high productive activities, increasing aggregate efficiency as well as improving equality (Moene and Wallerstein 1997, Agell and Lommerud 1993).

Whatever the benefits of solidaristic bargaining in terms of efficiency--a study of productivity growth in Sweden by Hibbs and Locking (2000) finds evidence that the gain in efficiency was substantial--the cumulative impact on the distribution of wages and salaries was large. "Equal pay for equal work" is a common demand of unions, easily explained by unions' desire to reduce managerial discretion. Solidaristic bargaining extended the principle of "equal pay for equal work" from one industry to the entire economy, and then moved beyond the demand for "equal pay for equal work" toward the goal of "equal pay for all work." In Sweden between 1970, when comprehensive wage data on individuals began to be collected, and 1983, when the system of centralized bargaining collapsed, the variance of the log of hourly wages among private sector bluecollar workers declined by over 50 per cent (Hibbs and Locking 2000). That dramatic decrease does not include the equally prominent reduction of the wage differential between blue-collar and white-collar workers. Hibbs and Locking (2000) estimate that a similar decline occurred during the 1960s as well, implying that the variance of log hourly wages in 1983 was only one quarter of what it was in 1960. In 1992, the ratio of the wage for a worker at the 90th percentile of the wage distribution to the wage for a worker at the 10th percentile was about 2 to 1 in Sweden, Norway and Denmark, the lowest ratios of any country in the OECD (OECD 1996). In contrast, the 90-10 ratio was 5.4 to 1 in the US in 1992.

Many other features of the Nordic model of social democracy follow from the policy of wage compression. Wage compression directly encouraged the movement of 
capital from less productive to more productive activities, but the effect on the incentives for workers to change occupations was mixed. While wage compression would increase job loss in industries with low productivity and job creation in industries with high productivity, employers in highly productive firms lost the ability to attract workers with the offer of higher pay. The government, unions and employers responded to the problem with an array of active labor market policies that subsidized the movement of workers from one industry to another with training programs and grants to cover moving expenses. To keep highly productive employers from undermining the policy of wage restraint by offering workers generous benefits (which were harder than wages to monitor at the central level), the Swedish employers' confederation lobbied the government to nationalize the provision of health care and pensions (Swenson 2002). Moene and Wallerstein (2001) show that expenditures on social insurance against the loss of income due to unemployment, disability, sickness and occupational injury rises as wage inequality declines. If insurance is a normal good, a policy that raises the income of the majority of workers with below average incomes increases the political demand for social insurance policies. The compression of wage differentials, in sum, had far-reaching economic and political consequences, one of which, we argue in the next section, was to increase the pace of economic development.

\section{A Simple Model of Development}

To see the potential importance of wage compression for economic development, we present a simple model of a developing economy. The central aspect of development that the model incorporates is that the growth of a modern industrial sector at the expense of traditional production depends on the size of the market for modern goods. ${ }^{5}$ The model 
distinguishes between modern and traditional sectors depending on the technology they apply. While old technologies have decreasing returns to scale, new technologies have increasing returns. As new technologies require fixed cost outlays, however, the profitability of modern plants depends on the size of the market. Foreign demand for the output of the modern sector, we assume, is exogenous. Domestic demand, in contrast, is assumed to be an increasing function of the size of the modern sector. The idea is that many consumers of modern sector goods are other modern sector firms or workers in the modern sector. The dependence of the growth of the modern sector on the size of the modern sector creates a feedback loop. The result may be a poverty trap, in which growth fails to occur, or sustained development in which initial growth of the modern sector encourages further modern sector growth until the traditional sector disappears. A central determinant of whether the economy develops or not that we emphasize in this model is the wage differential between modern and traditional sectors.

We start with the modern sector. Let $x$ represent both the value of output and employment in a representative modern sector plant. We assume, in other words, we that one unit of labor is required to produce one unit's worth of revenue for the enterprise. Labor is the only variable cost of production. In addition, we assume that there is a fixed cost of plant and equipment, $c$, associated with modern sector enterprises. Implicitly we have assumed that the minimum plant size is large enough to supply the domestic market. Note that we have assumed a form of increasing returns to scale in the modern sector, since the average cost of production decline as output increases. If workers in modern sector plants receive a wage of $w$, then profit per modern sector plant can be written as

$$
\pi=(1-w) x-c
$$


Modern sector workers, we assume, are covered by collective agreements. If wage bargaining is decentralized, the wage agreement depends on the two sides' willingness to engage in industrial conflict. In the event of a work stoppage, we assume that modern sector workers receive an income roughly equivalent to what workers earn in the traditional sector, which we denote by $q$, while firms receive $-c$, since sunk costs are sunk. Applying the generalized Nash bargaining solution implies a modern sector wage of

$$
w=q+\beta(1-q)
$$

where $\beta \in[0,1]$ represents workers' share of the joint surplus in bargaining. Equation (2) implies that profits in the modern sector can be written as

$$
\pi=(1-\beta)(1-q) x-c
$$

The demand for modern sector output depends on foreign demand and domestic demand. Domestic demand, in turn, depends on the size of the modern sector. In particular, we assume that a fixed proportion of modern sector income is spent on the output of domestic modern sector firms. It follows that the demand for modern sector output is an increasing, strictly convex function of the size of the modern sector, or $x=$ $x(n)$ where $n$ represents the share of modern commodities produced by domestic firms. . (See the appendix for a full description of the model.) Implicit in our formulation is a view of development as consisting of a form of import substitution as domestic modern sector firms replace foreign suppliers of modern commodities for the domestic market. In other words, we assume some degree of home market bias, such that domestic producers are preferred in the domestic market over imports. Imports may rise with development, however, as increasing income in the modern sector generates greater 
demand the full range of modern sector commodities, including those that are not produced domestically.

The fixed costs include normal returns on capital. Thus, negative profits imply disinvestment while positive profits imply increasing investment in modern sector plants. This is captured by assuming that the change in the size of the modern sector over time, or $d n / d t$, is given by the equation

$$
d n / d t=k \pi(x(n))
$$

where $k$ is a positive constant. For a given wage, equations (1) and (4) imply that there is a minimum size, $n^{*}$, such that modern sector growth is positive. Indeed, if $n>n^{*}$, the growth of the modern sector is an increasing, convex function of the size of the modern sector if there is sufficient excess labor in the traditional sector such that $\mathrm{q}$ remains constant. Alternatively, for a given size of the modern sector, $n$, equations (3) and (4) imply that there is a maximum wage differential $w-q=\beta(1-q)$ such that modern sector growth is positive. A wage differential that is too large is incompatible with sustained development.

The impact of the wage differential between the modern and traditional sector on the growth of the modern sector is illustrated in Figure 1. The upward sloping curve represents the value of $\beta$ such that profits are zero. If the initial combination of $\beta$ and $n$ is below the curve, profits are positive and the modern sector grows. If the initial combination of $\beta$ and $n$ is above the curve, however, profits are negative and the modern sector declines.

Figure 1 about here 
The assumption that unions would push the modern sector into extinction if they could seems extreme. A reasonable modification would be that unions limit their wage demands to the level that is compatible with constant modern sector employment. The wage would be given by whichever is less, $w=\beta+(1-\beta) q$ or $w=1-(c / x)$. In this case, the alternative to sustained development is stagnation, not decline. The conditions for sustained development, however, are unchanged. A sufficiently high wage differential between modern and traditional sector workers blocks development.

To complete the model, we need to include the determination of earnings in the traditional sector and unemployment. Earnings in the traditional sector are assumed to be a declining function of the number of workers seeking traditional sector employment, $q=$ $q(l)$, with $d q / d l \leq 0$, where $l$ is the number of workers employed in the traditional sector. Production in the modern sector is typically geographically concentrated. To be available for modern sector employment, workers may have to leave the countryside and their source of traditional sector employment. Let $u$ be the ratio of unemployed workers to modern sector workers so that $u n$ is the number of workers who are unemployed, and let $f(u)$ be the probability of obtaining a modern sector job, where $f(0)=1$ and $f^{\prime}(u)<0$. With these assumptions, migration takes place until expected earnings are identical in the two sectors, that is until

$$
f(u) w=q(l)
$$

This expression is just a variant of the Harris-Todaro (1970) mechanism for rural urban migration.

As long as modern sector workers have bargaining power that is derived from their ability to shut down production, wages don't fall to clear the urban labor market. ${ }^{6}$ 
Unemployment is involuntary in the sense that the unemployed would prefer to work at the wage that is offered by modern sector firms, the unemployed are not worse off than workers who remain in the traditional sector. Finally, the share of workers who are employed in modern enterprises, unemployed and employed in traditional activities must equal the total labor force, $L$, or $n x+u n x+l=L$.

The allocation of labor and the distribution of earnings for a given $n$ are illustrated in Figure 2, with employment on the horizontal axis and earnings on the vertical axis. Employment in the modern sector is represented by the distance from the left-hand vertical axis while employment in the traditional sector is represented by the distance from the right hand vertical axis. Modern sector workers receive $w=\beta+(1-\beta) q$, which does not depend on employment in the modern sector, while traditional sector workers receive $q$, which is a declining or constant function of employment in the traditional sector. The number of unemployed workers is determined by the intersection of the curve $w f(u)$ and $q(l)$ since migration is assumed to equalize expected earnings of traditional sector workers and the unemployed.

Figure 2 about here

In Figure 2, the curve $q(l)$ is drawn as flat until the number of workers in the traditional sector becomes sufficiently small. A flat $q(l)$ curve represents the case of a labor surplus economy where expansion of the modern sector has little effect on earnings in traditional activities, as postulated by Lewis (1954). If wage differential between the modern and traditional sectors is sufficiently low, then the modern sector will grow and the traditional sector will decline. Eventually, the share of workers in the traditional 
sector will fall enough such that $q(l)$ and $w$ will rise. But if the wage differential is too high, the modern sector will stagnate or contract and development will not occur.

The model has Keynesian features in the sense modern sector output is determined by the level of demand. A positive demand shock, such as an increase in exports, $g$, implies higher modern sector employment with a multiplier greater than one. ${ }^{7}$ Thus an increase in the demand for modern sector exports, such as occurred for the Nordic countries with the revival of the German economy in the 1930s, may create conditions of sustained development. Although we haven't included a government sector in the model, it is easy to show that increased government spending on modern sector output has the same impact as an increase in foreign demand.

The simple model we have described omits important considerations. In particular, the treatment of prices and foreign demand as exogenous forces us to ignore the effect of wage demands on the competitiveness of exports, an important part of the Norwegian and Swedish story. But the model is sufficient for the purpose of demonstrating the potential importance of large wage differences between the modern and traditional sectors in blocking economic growth. Adding a channel whereby modern sector wage setting would effect foreign demand, in addition to domestic demand, is to add further reasons why growth might be increased by a policy of reducing the wages earned in the most productive enterprises. Reducing the share of surplus received by relatively privileged workers, we suggest, was the essence of the social democratic development strategy. Essentially, centralization took wage setting out of the hands of the unions representing relatively high-paid workers and put wage setting in the hands of leaders of the labor movement as a whole, which included almost everyone. 
In the end, the social democratic model of development owed more to Adam Smith than to Karl Marx. Both Adam Smith and the social democrats were ardent defenders of the poorest groups in society. Both saw modernization and expansion of markets as the key to escaping poverty. Both saw the primary task as being one of removing the obstacles to rapid modernization. Adam Smith viewed the primary obstacles to modernization as restrictions on the free movement of labor and capital, such as guild privileges and monopolies, that limited the size of the market and the extent of specialization. The social democrats, in effect, saw the primary obstacle to modernization as strong local unions whose wage premiums restricted the expansion of the most productive sectors. What distinguished the social democrats from more conservative followers of Adam Smith like Margaret Thatcher was their solution to the problem of restricting the power of local unions. While Thatcher's solution was to weaken unions as institutions, that social democratic approach was to strengthen unions as institutions and to structure collective bargaining in a highly centralized manner that reduced the influence of high-paid workers in the wage setting process.

\section{The Political Feasibility of Solidaristic Bargaining}

Many social democrats and non-social democrats alike would accept the argument that development can be promoted by reducing the wage differential between modern sector and traditional sector workers. What makes the social democratic experience exceptional was that the policy of wage compression was voluntary, not coerced, and implemented by a union movement that included as members many of the high-wage workers whose wages would be restrained in the name of greater equality. Thus, the great challenge faced by those who would apply the lessons of social democracy in the 
third world today is political. How can a democratic political movement with close ties to the unions implement a development strategy that centers on wage restraint?

It may be helpful to review the balance of political forces behind the implementation of solidaristic bargaining in the Nordic countries. One of the central groups who supported centralization in the 1930s and 1940s and solidaristic bargaining in the 1950s and 1960s were the employers (Swenson 1989, 1991). While the Nordic countries are well known the strength of unions, employers also achieved an extraordinary level of organization. Employers much preferred to bargain with the "sensible" leadership of the union confederations, rather than with the militant leadership of the shop floor union bodies. Moene and Wallerstein $(1997,2002)$ demonstrate that employers may be able to increase aggregate profits by reducing wage inequality relative to the wage schedule associated with decentralized bargaining and even relative to the wage schedule associated with a competitive labor market where employers set wages unilaterally.

The other important group that supported the policy of wage compression was the leadership of unions of low-wage workers. Since the union movement was encompassing, both low and high wage earners had influence in union policy. While the policy of wage compression was controversial in unions of high-wage workers, it was enthusiastically supported by unions of low-wage workers. Thus, the political coalition that prevailed in the $1950 \mathrm{~s}$ and established the pattern of centralized and solidaristic bargaining that was to last until the 1980s was comprised of the low-wage unions and employers. High-wage unions were prevented from leaving the centralized negotiations by the threat of lockouts. It is unlikely that the low-wage unions and the leadership of the 
union confederation would have been able to force the high-wage unions to accept an egalitarian wage policy without the backing of employers and the threat of lockouts against recalcitrant unions.

In addition, we believe that the policy found support in the widespread preference of Nordic workers for a more egalitarian wage scale. We do not believe that Nordic workers are inherently more egalitarian than other workers. Rather, our belief is that a preference for greater equality is widespread. The preference for greater equality can only be acted upon to the extent that wages are set centrally. When wages are set at the plant level, for example, wage compression can only occur within the plant. When wages are set at the industry level, wage compression occurs within the industry. When wages are set at the national level, wage compression occurs at the national level.

Social heterogeneity does not eliminate the preference for more egalitarian pay. Unions compress wages within the scope of the bargaining agreement even in racially and ethnically divided societies like the US (Freeman and Medoff 1984). European countries divided by religion, such as the Netherlands and Germany, or by language, such as Belgium, have relatively centralized wage setting institutions and relatively egalitarian wage distributions (Wallerstein 1999). But it is possible that the centralization of wage setting is easier to achieve in countries that are not divided by religion, language or race. It is highly likely that the centralization of wage setting is easier to achieve in countries with a small population.

The Nordic countries may have had another important advantage that countries in the third world today do not. At the end of the Second World War, when solidaristic bargaining began to be implemented, the Nordic economies were operating at full 
employment. Full employment may seem like inauspicious circumstances to implement a policy of wage restraint, but it had an important advantage that is illustrated in Figure 3. Figure 3 duplicates Figure 2, except that the $q(l)$ curve is upward sloping throughout. Without surplus labor, any increase in modern sector employment will lead to an increase in the earnings of traditional sector workers. Since $w=\beta+(1-\beta) q$, the rise in $q$ generated by the reduction in $\beta$ reduces the cost of solidaristic bargaining for modern sector workers. In addition, the increase in $q$ implies that all traditional sector workers benefit from higher wages, not just those who move from traditional sector to modern sector jobs.

Figure 3 about here.

\section{Conclusion}

Is the social democratic model of development relevant in the contemporary world of economies increasingly integrated in global markets for goods and capital? The social democrats were committed to free trade but not the free flow of capital. However, we have de-emphasized the importance of credit controls as an important part of the social democratic approach. The free flow of capital and goods would make a policy of reducing wage differentials more, not less, effective as a strategy of development.

Is the social democratic model of development politically feasible in the third world? This, it seems to us, is the critical question. The elements that appear to have been important in allowing wage differentials to be reduced through collective bargaining were (a) well organized employers, (b) encompassing trade unions that included the low-paid workers and (c) immediate benefits of wage compression in terms of the earnings of those at the bottom. These conditions are not notably present in Africa, Asia and Latin 
America today. But we still understand very little of the political dynamics that made wage compression possible in an environment with strong unions and a government that considered industrial workers to be its core constituents. Thus, we are reluctant to conclude that the social democratic experience cannot be repeated.

\section{Appendix}

In this section, we present the details of the model underlying Figure 1 in the text. Let there be a continuum of measure one of modern commodities, all with prices fixed on the international market. Of these modern commodities, the fraction $n$ is produced by local enterprises. For the sake of simplicity, we assume that each modern commodity is produced by one enterprise. As described in the text, output is linear in hours worked, with one unit of labor producing one unit of output. In addition, there are fixed costs of $c$ $>0$.

We assume that the fraction $\mu$ (with $\mu<1$ ) of modern sector income $(x-c) n$ is spent on each of the modern commodities. Thus, the domestic demand for each modern sector enterprise is $\mu n(x-c)$. If we write foreign demand for each modern commodity produced locally as $g$, the output and employment inn each modern sector enterprise is given by

$$
x=\mu n(x-c)+g
$$

Equation (6) implies that production and employment in modern enterprises is an increasing, convex function of $n$

$$
x(n)=\frac{g-\mu n c}{1-\mu n}
$$

provided $g>c$. If $g \leq c$, there is no wage low enough to make the first modern enterprise profitable. The assumption that the domestic demand for modern commodities is 
unaffected by the income earned in the traditional sector can easily be relaxed without altering the way the model works. The central assumption is that the growth of the modern sector increases the demand for modern sector output and higher output in the modern sector lowers the average costs of production.

Given a wage of $w=\beta+(1-\beta) q$, the condition that profits are positive and the modern sector grows can be written in terms of the size of the modern sector:

$$
\pi>0 \Leftrightarrow n>\frac{c-(1-\beta)(1-q) g}{\mu c[1-(1-\beta)(1-q)]} \equiv n *
$$

Note that the minimum size compatible with sustained development, $n^{*}$, is an increasing function of $c, \beta$ and $q$, and a decreasing function of $\mu$ and $g$.

Alternatively, we can write the condition that profits are positive in terms of the share of the joint surplus obtained by modern sector workers:

$$
\pi>0 \Leftrightarrow \beta<\left(\frac{1}{1-q}\right)\left[\frac{g-c}{g-\mu c n}-q\right] \equiv \beta *
$$

The maximum share of the surplus compatible with sustained development, $\beta^{*}$, is an increasing, strictly convex function of $n$. This is the function drawn in Figure 1 in the text. 


\section{Endnotes}

${ }^{1}$ Another policy innovation associated with social democracy that is much discussed is the development of active labor market policies, that is policies that offer retraining to the unemployed in place of unemployment benefits. We emphasize solidaristic bargaining because we think it had far more important effects on both equality and growth.

${ }^{2}$ See Hodne and Grytten (1992) for a discussion.

${ }^{3}$ Swenson $(1989,1991)$ describes the events in Sweden. The similar events in Norway are described by Bjørgum (1985).

${ }^{4}$ See Wallerstein and Golden (1997) for a survey of the rise and decline of centralized bargaining in Denmark, Norway, Sweden and Finland.

${ }^{5}$ For an empirical study that presents evidence in support of our assumption that growth is driven by the size of the internal market and exports demand, see Aides and Glaeser (1999).

${ }^{6}$ The presence of unions is not the only reason why wages in the modern sector might fail to fall to clear the urban labor market. Even if unions were absent, employers may not reduce wages until unemployment is eliminated for fear of the effect of wage reductions on workers' effort and turnover. See Weiss (1990) for a review of the literature.

${ }^{7}$ That the multiplier is greater than one follows immediately from the expression for $x$ as a function of $g$ and $n$ in the appendix. 


\section{References}

Agell, Jonas and Kjell Erik Lommerud. 1993. Egalitarianism and Growth. Scandinavian Journal of Economics, 95: 559-579.

Aides, Alberto F. and Edward L. Glaeser. 1999. Evidence on Growth, Increasing Returns and the Extent of the Market. Quarterly Journal of Economics, 114(3): $1025-1045$.

Alesina, Alberto, Edward Glaeser and Bruce Sacerdote. 2001. Why Doesn't the US Have a European-Style Welfare State? Paper presented at the Brookings Panel on Economic Activity, Sept. 7, 2001, Washington DC: Brookings Institution.

Bjørgum, Jorunn. 1985. LO og NAF 1899-1940. Tidsskrift for Arbeiderbevegelsens Historie, 1985, Nr. 2: 85-114.

Center for International Comparisons. 2002. Penn World Table 6.0. University of Pennsylvania, Center for International Comparisons: www.pwt.econ.upenn.edu/.

Falk, Torben and Per Tovmo. 2000. Norwegian Local Public Finance in the 1930s.

Unpublished paper, Norwegian University of Science and Technology. Trondheim, Norway.

Freeman, Richard B. 1988. Labour Market Institutions and Economic Performance. Economic Policy, 3: 64-80.

Freeman, Richard B. and James L. Medoff. 1984. What Do Unions Do? New York: Basic Books.

Frisch, Ragnar. 1931. Plan eller kaos. Tidens Tegn, November 5, 1931. 
Harris, John R. and Michael P. Todaro. 1970. Migration, Unemployment and Development: A Two-Sector Analysis. American Economic Review, 60., 126142.

Hibbs, Douglas A. Jr. and Håkan Locking. 2000. Wage Dispersion and Productive Efficiency: Evidence for Sweden. Journal of Labor Economics, 18 (4): 755--782.

Hicks, Alexander. 1999. Social Democracy and Welfare Capitalism: A Century of Income Security Politics. Ithaca NY: Cornell University Press.

Hodne, Fritz and Ola Honningdal Grytten. 1992. Norsk Økonomi 1900-1990. Oslo: Tano.

Huber, Evelyne and John Stephens. 2001. Development and Crisis of the Welfare State. Chicago: University of Chicago Press.

Ingham, Geoffrey. 1974. Strikes and Industrial Conflict: Britain and Scandinavia. London: MacMillan.

Lewis, Arthur. 1954 Economic Development with Unlimited supplies of Labour. The Manchester School 22, 139-191.

Maddison, Angus. 1964. Economic Growth in the West. New York: Norton.

Moene, Karl Ove and Michael Wallerstein. 1997. Pay Inequality. Journal of Labor Economics, 15: 403--430.

Moene, Karl Ove and Michael Wallerstein. 2001. Inequality, Social Insurance and Redistribution. American Political Science Review, 95(4): 859--874.

Moene, Karl Ove and Michael Wallerstein. 2002. Does the Logic of Collective Action Explain the Logic of Corporatism? Northwestern University: unpublished paper. 
Organization for Economic Cooperation and Development. 1996. Employment Outlook, July. Paris: OECD.

Rehn, Gøsta. 1952. The Problem of Stability: An Analysis of some Policy Proposals. In Ralph Turvey, ed., Wages Policy under Full Employment. London: W. Hodge.

Sen, Amartya. 1975. Employment, Technology and Development. Oxford. Clarendon Press.

Smith, Adam. 1976 [1776]. An Inquiry into the Nature and Causes of the Wealth of Nations. Chicago: University of Chicago Press.

Statistics Norway. 1995. Historical Statistics. Oslo: Central Bureau of Statistics.

Swenson, Peter. 1989. Fair shares: Unions, Pay and Politics in Sweden and West Germany. Ithaca: Cornell University Press.

Swenson, Peter. 1991. Bringing Capital Back In, or Social Democracy. World Politics, 43(4): 513-544.

Swenson, Peter. 2002. Capitalists against Markets. Oxford: Oxford University Press.

Therborn, Göran. 1986. Why Some Peoples are More Unemployed than Others. London: Verso.

Wallerstein, Michael. 1999. Wage-Setting Institutions and Pay Inequality in Advanced Industrial Societies. American Journal of Political Science, 43: 649-680.

Wallerstein, Michael and Miriam Golden. 1997. The Fragmentation of the Bargaining Society: Wage-Setting in the Nordic Countries, 1950-1992. Comparative Political Studies, 30(6): 699-731.

Weiss, Andrew. 1990. Efficiency Wages. Princeton: Princeton University Press.

Wilensky, Harold. 2002. Rich Democracies. Berkeley: University of California Press. 
World Bank. 2002. World Development Indicators. Washington DC: World Bank. 
Figure 1: Workers' Share of the Surplus, the Size of the Modern Sector, and Growth

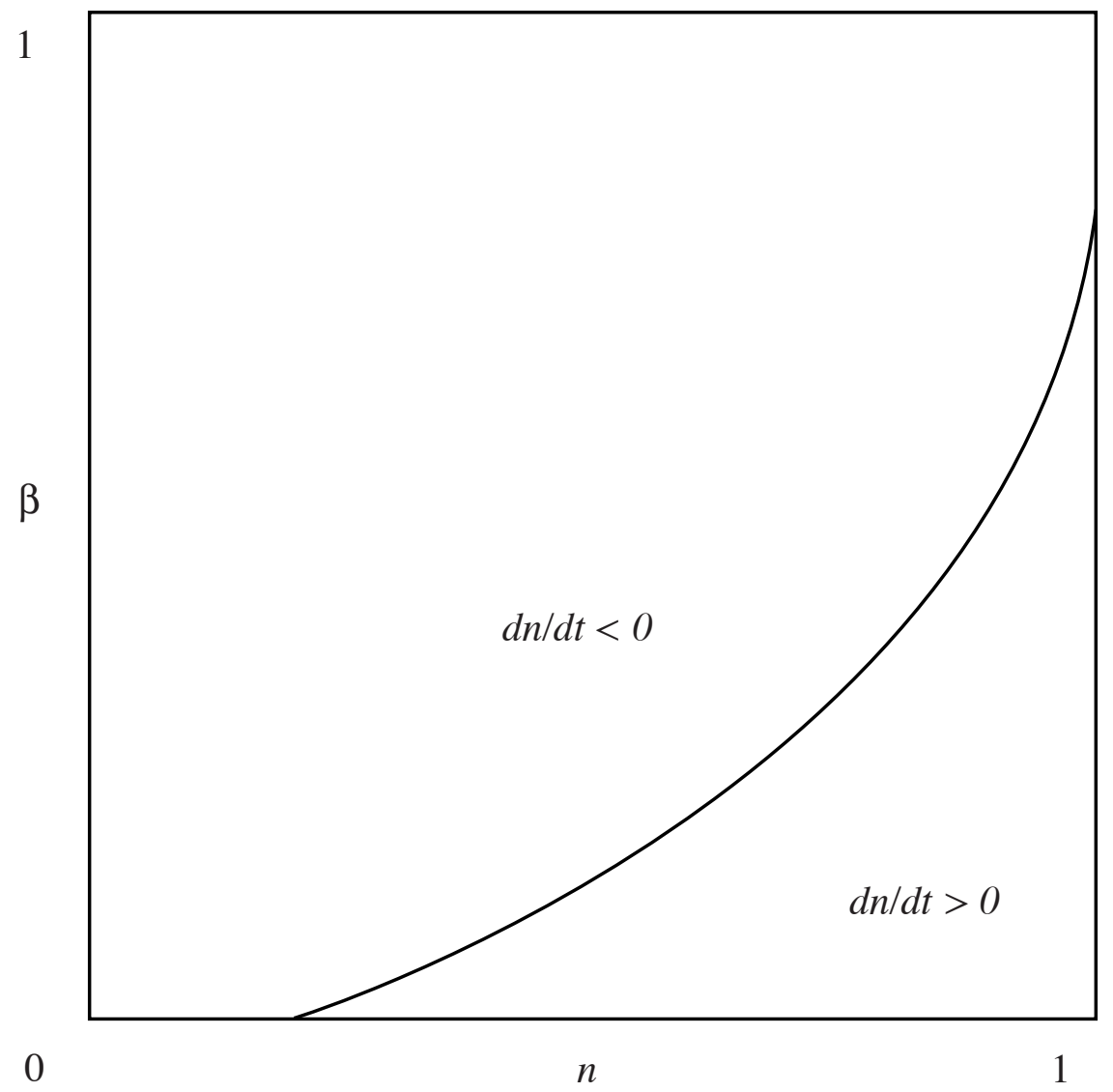


Figure 2: Wages and Employment

with Surplus Labor

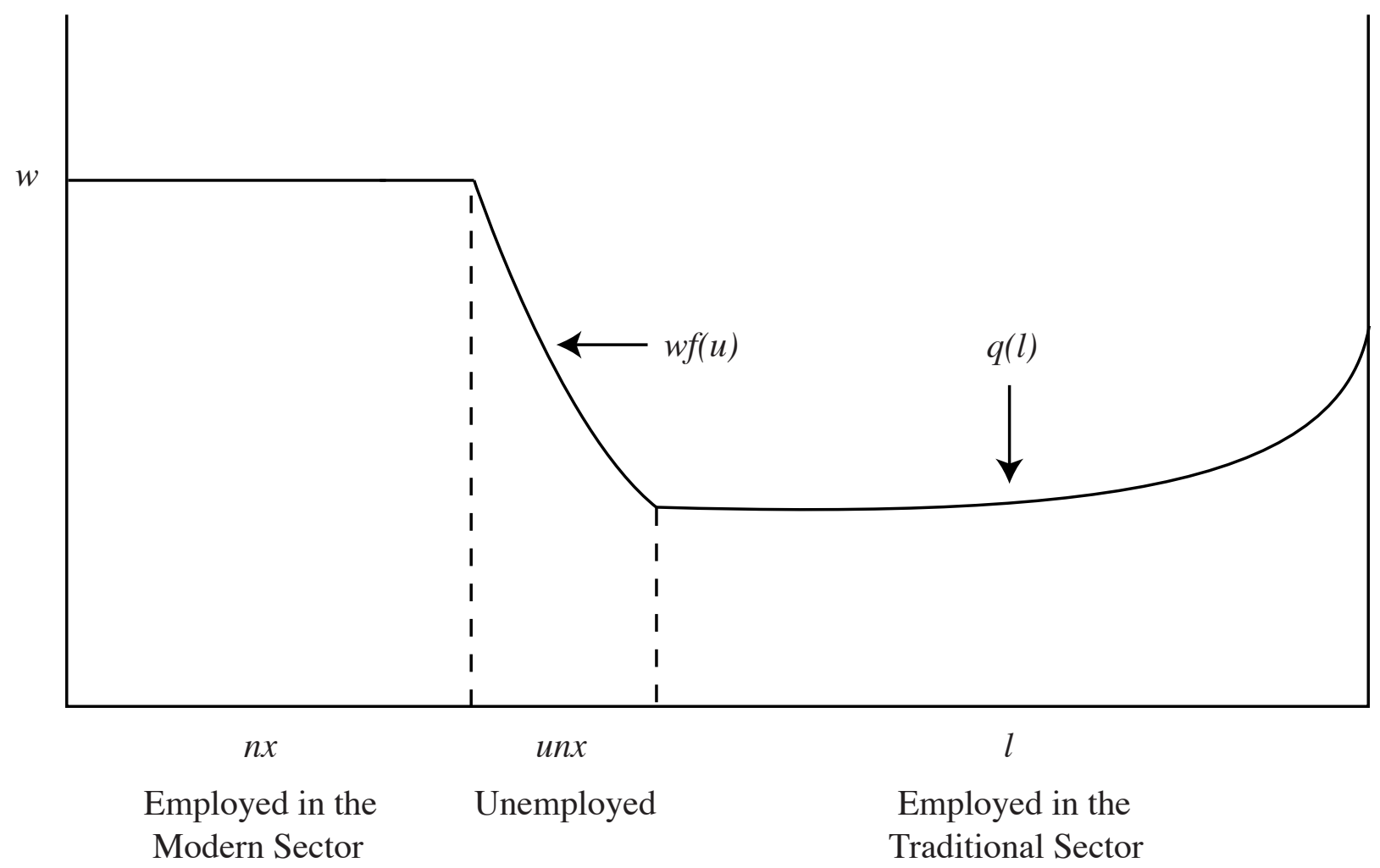


Figure 3: Wages and Employment without Surplus Labor

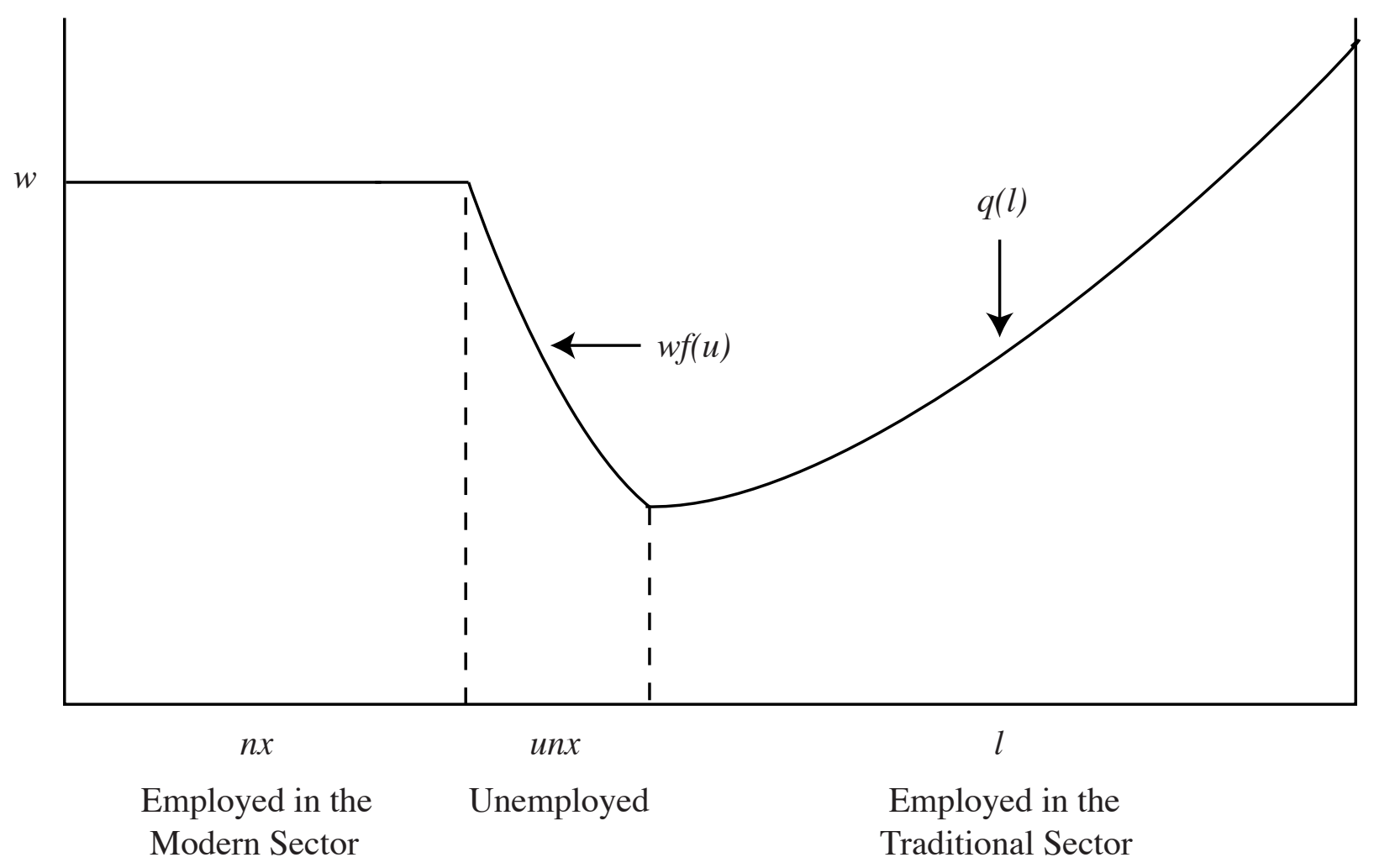

